\title{
高温純水中におけるステンレス鋼の金属放出に及ぼす 表面酸化処理条件の影響*
}

\author{
藤原和雄**, 泊里治夫**, 中山武典**, 下郡一利** \\ ** (株) 神戸製鋼所材料研究所
}

\section{Effects of Surface Oxidation Conditions on Metal Release of a Stainless Steel in High Temperature Pure Water*}

\author{
Kazuo Fujiwara** Haruo Tomari**, Takenori Nakayama** \\ and Kazutoshi Shimogori** \\ ** Materials Research Laboratories, Kobe Steel Ltd.
}

\begin{abstract}
In order to study the effect of oxidation conditions on the metal release of Type 304SS in high temperature pure water, the specimens oxidized in various environments such as air, steam or water were immersed in deionized and deaerated water of $180^{\circ} \mathrm{C}$, and metal release level was measured by weight loss. The behavior of metal release was also discussed in relation to the surface film which was formed by oxidation treatment. As the results, the oxidation treatments in air at $425^{\circ} \mathrm{C}$ and in steam at $350^{\circ} \mathrm{C}$ were found to be specially effective to decrease the metal dissolution compared with those of mechanical polishing and the oxidation in water. The results corresponded well with the structure of surface films.
\end{abstract}

Key words: stainless steel, high temperature water, metal release, prefilming

\section{1. 緒言}

軽水型原子炉の運転年数の増加とともに，点検従事者 の放射線被曝が増大する傾向が見られるが，これは原子 炉 1 次系の構造材料から冷却水中に放出した極く微量の 腐食生成物が炬心の燃料被覆管表面で放射化されて放射 性腐食生成物となり，その一部が炉水を介して炬心外の 配管や機器に付着することが主な原因とされてい

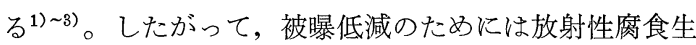
成物の発生量を低減することが効果的な対策の一つであ り, 構造材料面からは低 Co 含有材の使用などにより顕 著な効果が認められている4) が，より一層の被曝低減対

* 表面酸化処理によるステンレス鋼の金属放出抑制 に関する研究一第 1 報 (Study on Inhibition of Metal Release by Surface Oxidation Treatment of Stainless Steels-The First Report)

** 干651 神戸市中央区脇浜町 1 丁目 3-18 (3-18, 1chome, Wakinohama-cho, Chuo-ku, Kobe 651 Japan)
策が望まれている。

このような背景から，構成材料をあらかじめ高温水に 曝してその表面に酸化皮膜を形成して腐食を抑制する技 術が提案されている4) 6)。本研究では広範囲の条件下で ステンレス鋼に表面酸化処理を施し，高温純水中に和け る放出特性に及ぼす酸化処理条件の影響を表面皮膜性状 との関連で検討したので以下に報告する。

\section{2. 実験方法}

\section{1 供試材料及び試験片}

供試材料は Table 1 亿化学組成を示す SUS $304 \mathrm{~L}$ で, 肉厚 $2 \mathrm{~mm}$ の市販の冷間圧延鋼板を用いた。この鋼板よ り Fig. 1 に示す形状の試験片を切り出し，これらの試 験片の全表面に\#600 湿式エメリ一研磨を施した後, $200 \sim 600^{\circ} \mathrm{C}$ の大気中, $200 \sim 450^{\circ} \mathrm{C}$ の非脱気水蒸気中及 び $200 \sim 350^{\circ} \mathrm{C}$ の所定組成の水中にて所定時間酸化処理 を行った。 
Table 1 Chemical composition of steel tested.

\begin{tabular}{|c|c|c|c|c|c|c|c|c|}
\hline \multirow{2}{*}{ Steel } & \multicolumn{7}{|c|}{ Chemical Composition (\%) } \\
\cline { 2 - 9 } & $\mathrm{C}$ & $\mathrm{Si}$ & $\mathrm{Mn}$ & $\mathrm{P}$ & $\mathrm{S}$ & $\mathrm{Ni}$ & $\mathrm{Cr}$ & $\mathrm{Co}$ \\
\hline SUS304L & 0.017 & 0.58 & 0.96 & 0.025 & 0.005 & 9.56 & 18.13 & 0.22 \\
\hline
\end{tabular}

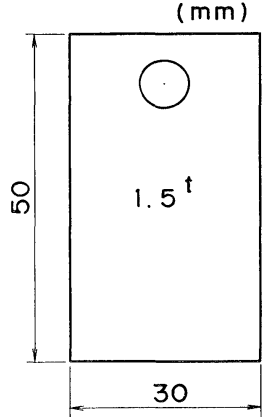

Fig. 1 Immersion test specimen.

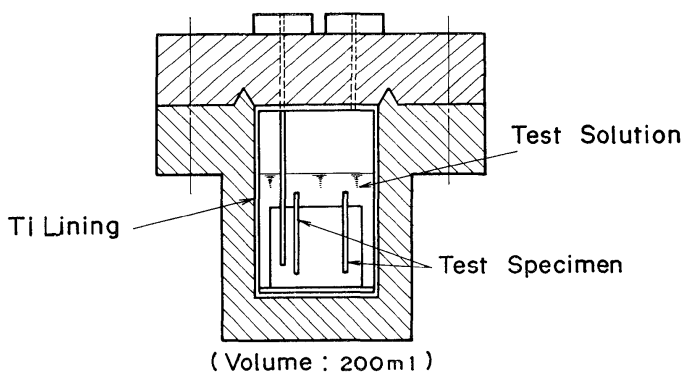

Fig. 2 Immersion test vessel.

\section{2 オートクレーブ浸漬試験}

金属放出試験は Fig. 2 に示す静止型 $\mathrm{Ti}$ ライニング製

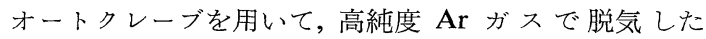
$180^{\circ} \mathrm{C}$ のイオン交換水 (比電導度 $\leqq 0.2 \mu \mathrm{S} / \mathrm{cm}$ ) 中に上 記試験片を最高 4,320 時間まで全面浸漬することにより 行った。金属放出量は浸漬前と塩基性過マンガン酸カ リ/クエン酸アンモン法によってスケールを除去した後 の重量を $10 \mu \mathrm{g}$ の科量感度を有する電子精密天科を用い て測定し，次式に従って全放出量として評価した。

$$
W_{s}=W_{2}-W_{4}+\alpha\left(W_{1}+W_{4}-W_{2}-W_{3}\right)
$$

$W_{s}$ : 全金属放出量, $W_{1}$ : 酸化皮膜付き試験片の金属分 重量, $W_{2}$ : 酸化皮膜付き試験片重量, $W_{3}$ : 浸漬後の金属 部分重量, $W_{4}$ : 浸漬後の重量, $\alpha$ : 定数（酸化皮膜組成を $\mathrm{M}_{2} \mathrm{O}_{3}$ と仮定して $\approx 0.3$ )

\section{3 表面皮膜解析}

金属放出試験前後の表面皮膜については, 走査型電子 顕微鏡観察 $(\mathrm{SEM})$, オージェ電子分光分析 (AES, PHI90), イオンマイクロ質量分析 (IMA, HITACHI IMA-3) 及びレーザーラマン 分光分析 (LRS, JASCO-NR1000)
により解析を行った。LRS の散乱スペクトルの解析は, 皮膜として生成する可能性のある $\mathrm{Fe}, \mathrm{Ni}, \mathrm{Cr}$ 系の酸化 物や水酸化物の標準スペクトルをとり，それらと対比す ることにより行った。

\section{3. 実験結果}

\section{1 金属放出に及ぼす大気酸化処理条件の影響}

種々の条件で大気酸化処理を施した試料の金属放出試 験結果を Fig. 3 に示す。図中の数字は各酸化処理材につ いて $180^{\circ} \mathrm{C}$ の脱気純水中に 2 週間浸漬した後の金属放 出量の非処理材からの金属放出量に対する比率を示して いる。また，実線で囲まれた領域は非処理材に対する比

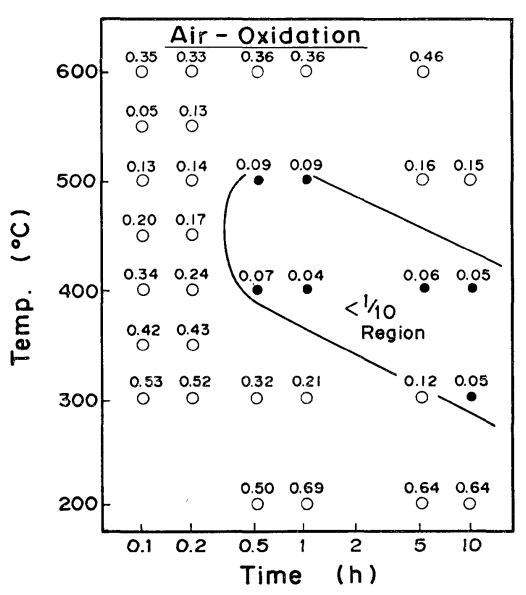

Fig. 3 Effect of air-oxidation conditions on metal release into deaerated pure water at $180^{\circ} \mathrm{C}$ (Numerals show the ratio to aspolished specimen).

率が $1 / 10$ 以下となる酸化処理条件を示すが，300 $500^{\circ} \mathrm{C}$ の範囲で, 特定時間酸化処理を施すことにより金 属放出量の著しく減少することがわかる。

これらの結果より最適大気酸化処理条件として $425^{\circ} \mathrm{C} \times 1$ 時間を選定した。

\section{2 金属放出に及ぼす 水 蒸気及び 水中酸化処理条件 の影響}

種々の条件で水蒸気及び水中酸化処理を施した試料の 金属放出試験結果を Fig. 4 に示す。この場合, 水中処理 には常温で大気平衡分の溶存酸素を含も非脱気のイオン 交換水を用いた。図中の数字は Fig. 3 の場合と同様放 


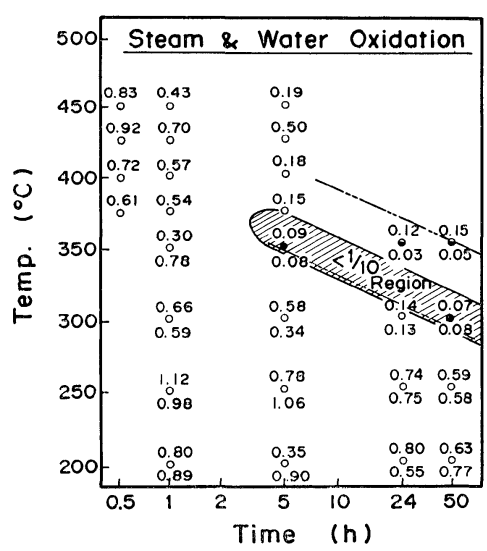

Fig. 4 Effect of steam- and water-oxidation conditions on metal release into deaerated pure water at $180^{\circ} \mathrm{C}$ (Numerals show the ratio to as-polished specimen. upper row: steam, lower row: water).

出量を示すパラメーターであるが，上段は水蒸気酸化， 下段は水中酸化の場合の值を示す。水蒸気酸化では 300
〜350 ${ }^{\circ} \mathrm{C}$ で特定時間酸化処理を施した場合に非処理材の 1/10 以下となり, また水中酸化でも $300 \sim 350^{\circ} \mathrm{C}$ の範囲 に金属放出量の最小領域が存在するが $1 / 10$ 以下となる 領域は水中酸化の場合の方がやや広くなっている。

これらの結果より, 金属放出量が非処理材の $1 / 10$ 以下 となる最適水蒸気酸化処理及び水中酸化処理条件とし て，それぞれ $350^{\circ} \mathrm{C} \times 10$ 時間及び $350^{\circ} \mathrm{C} \times 24$ 時間を選 定した。

\section{3 水中酸化処理材の金属放出に 及ぼす添加イオン の影響}

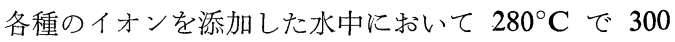
時間の酸化処理を施した試料について, $180^{\circ} \mathrm{C}$ の脱気純 水中で 2 週間の浸漬試験を行った場合に拐ける金属放出 量を Fig. 5 に示す。図中で金属イオンは Zn に関する 米国 $\mathrm{GE}$ 社の報告 ${ }^{5), 6)}$ を参考にして塩化物の形で添加し た。 $\mathrm{Zn}^{2+}, \mathrm{Sn}^{4+}, \mathrm{Al}^{3+}, \mathrm{Mg}^{2+}, \mathrm{Ca}^{2+}, \mathrm{BO}_{3}{ }^{3-}, \mathrm{CrO}_{4}{ }^{2-}$, $\mathrm{MoO}_{4}{ }^{2-}, \mathrm{WO}_{4}{ }^{2-}$ の添加が 無添加の場合（図中の pure water) に比べて金属放出量低減効果を示したが，いずれ も前記の大気酸化処理材や水蒸気酸化処理材に比べて効

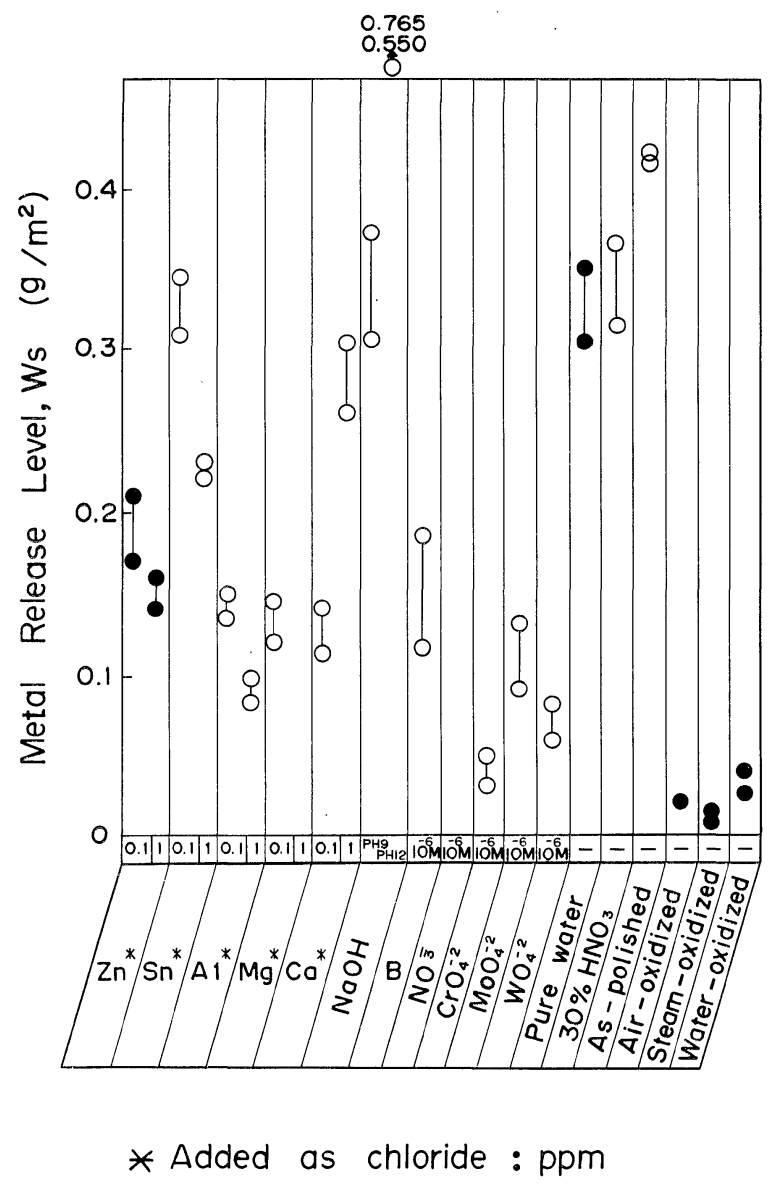

Fig. 5 Metal release level into deaerated water at $180^{\circ} \mathrm{C}$ from preoxidized specimens in $280^{\circ} \mathrm{C}$ water containing various additives for 300 hours. 


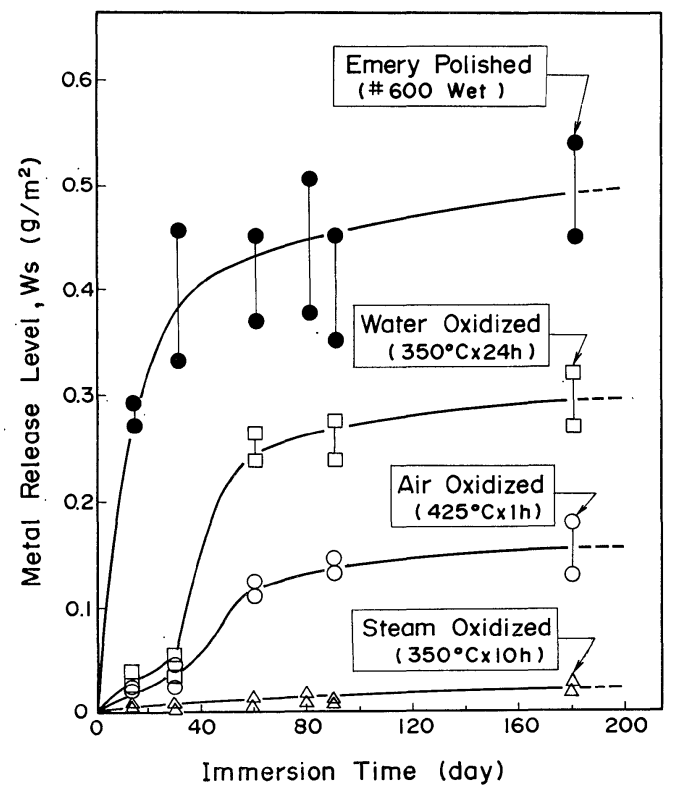

Fig. 6 Change of metal release with immersion time into deaerated pure water at $180^{\circ} \mathrm{C}$ on pure-oxidized specimens under representative conditions.
果は小さいことが明らかである。

\section{4 金属放出量, 表面性状及び皮膜構造の経時変化}

以上の結果より選出した最適酸化処理材 (大気酸化: $425^{\circ} \mathrm{C} \times 1$ 時間, 水蒸気酸化: $350^{\circ} \mathrm{C} \times 10$ 時間, 水中酸化: $350^{\circ} \mathrm{C} \times 24$ 時間) について長期の高温純水浸漬試験を行 い, 金属放出量, 表面性状及び皮膜構造の経時变化を調 査した。

金属放出量の経時変化を Fig. 6 に示す。非処理材も 含めいずれの処理材も浸漬初期の放出量は大きいが浸漬 時間の経過之共に放出速度が低下する。各処理材間の放 出量の序列は非処理材 $>$ 水中酸化処理材 $>$ 大気酸化処理 材>水蒸気酸化処理材の順であり, 特に水蒸気酸化処理 材の 6 力月浸漬後の放出量は非処理材の約 $1 / 20$ となっ ている。

各酸化処理材の処理まま及び高温脱気純水中に浸漬後 の表面皮膜のレーザーラマン散乱スペクトルを Fig. 7 に示す。処理ままではいずれの酸化処理皮膜についても $\mathrm{Fe}_{2} \mathrm{O}_{3}$ と $\mathrm{FeCr}_{2} \mathrm{O}_{4}(\mathrm{Fe}-\mathrm{Cr}$ スピネル) とから成っている が、大気酸化処理皮膜は 2 力月間浸漬後より $\mathrm{NiFe}_{2} \mathrm{O}_{4}$ (Niフェライト) が成長して扣り，Fig. 6 に特ける金属 放出量の急増現象とよく対応している。一方，水蒸気酸 化処理皮膜及び水中酸化処理皮膜は 3 力月間浸漬後にお てもい $\mathrm{Fe}_{2} \mathrm{O}_{3}$ と $\mathrm{FeCr}_{2} \mathrm{O}_{4}$ から成って括り，皮膜構造に

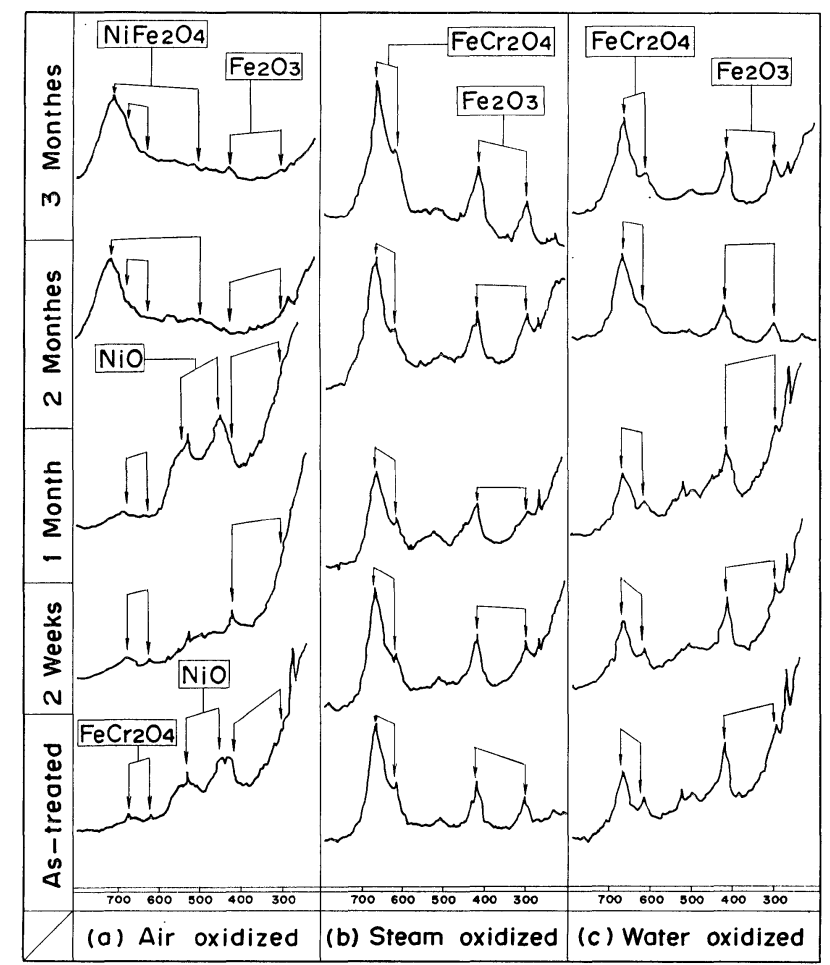

Fig. 7 Change of laser raman spectra with immersion time on preoxidized specimens under representative conditions. 

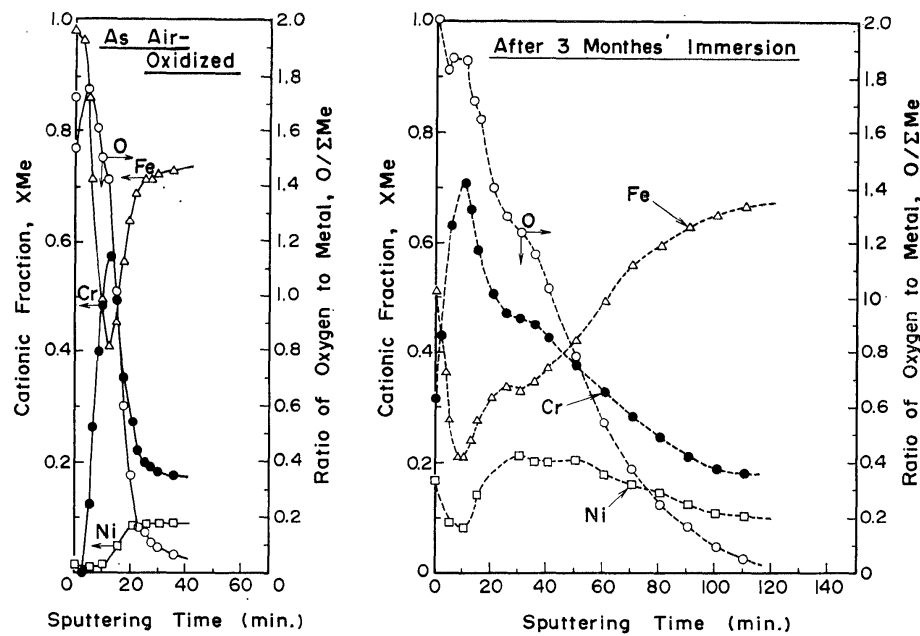

Fig. 8 Change of AES in-depth profiles of air-oxidized specimen by 3 month's immersion in deaerated pure water at $180^{\circ} \mathrm{C}$.

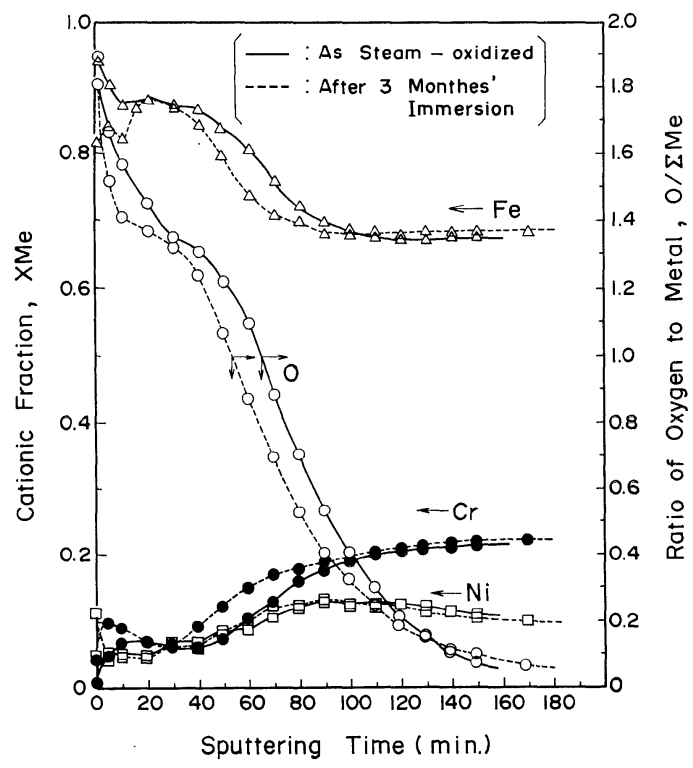

Fig. 9 Change of AES in-depth profiles of steam-oxidized specimen by 3 month's immersion in deaerated pure water at $180^{\circ} \mathrm{C}$.

は大きな変化は認められない。

Fig. 8 10 は各酸化処理皮膜の処理まま及び高温脱気 純水中 3 力月間浸漬後に括ける AES による皮膜組成分 析結果を示す。大気酸化処理材は 3 力月間浸漬後には皮 膜厚さが増大し，また Ni， Cr に富む組成に変質してい ることがわかる(Fig. 8)。水蒸気酸化処理材は 3 力月間 浸漬後に执いても皮膜厚さ及び皮膜組成に特別な変化は 認められない(Fig. 9)。一方, 水中酸化処理材は 3 力月 間浸漬後皮膜厚さが若干減少し，また $\mathrm{Ni} ， \mathrm{Cr}$ に富む皮

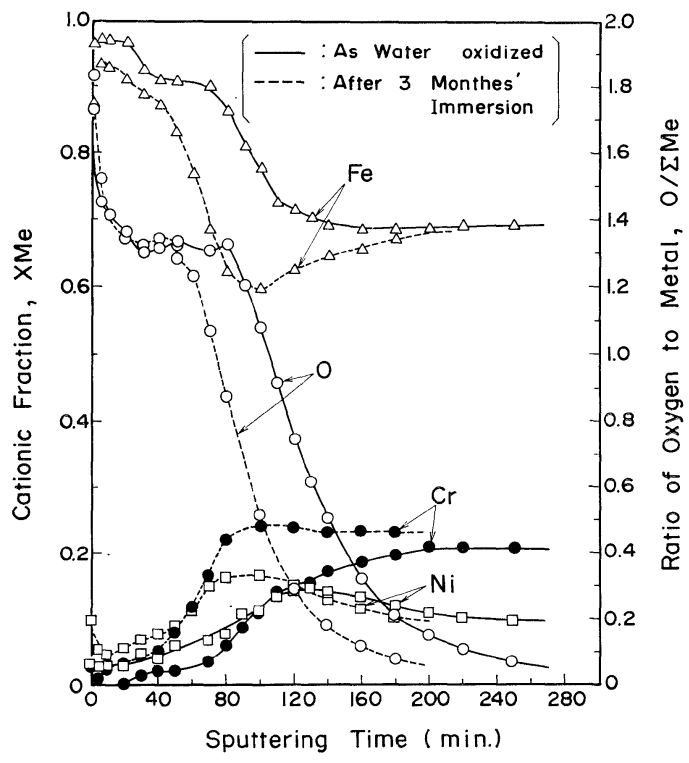

Fig. 10 Change of AES in-depth profiles $f$ water-oxidized specimen by 3 month's immersion in deaeratedd pure water at $180^{\circ} \mathrm{C}$.

膜に変質している(Fig. 10)。これらの傾向は IMA によ る分析でも確認された。

各酸化処理材の処理まま及び高温脱気純水中 3 力月間 浸漬後の表面性状の SEM による観察結果を Fig. 11 に 示す。大気酸化処理皮膜は処理ままでは平滑で緻密な構 造であるが，3 カ月間浸漬後には微細な粒状の物質が成 長している。水蒸気酸化処理皮膜は処理ままも 3 力月間 浸漬後もいずれも平滑で緻密な表面状況を示し，何ら変 化は認められなかった。一方，水中酸化処理皮膜は処理 


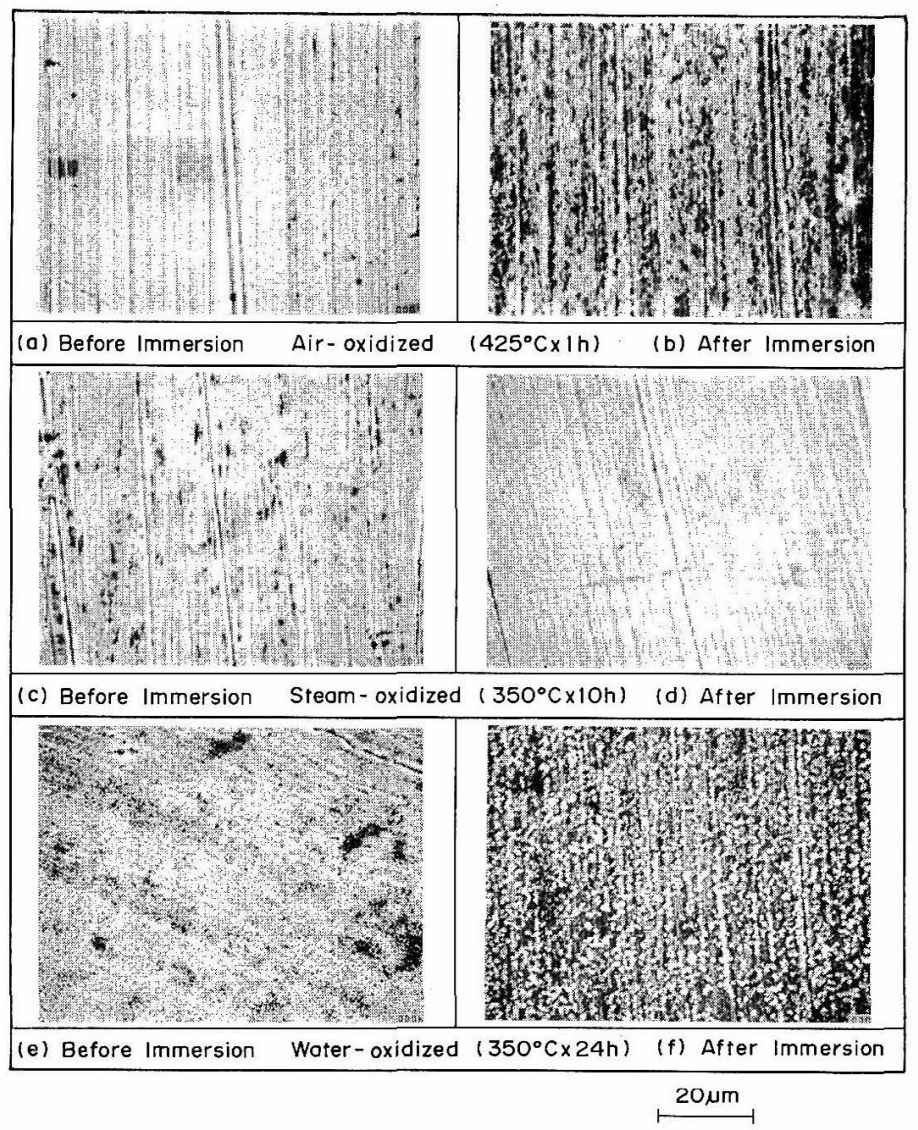

Fig. 11 Surface appearance of pre-oxidized specimens before and after immersion in deaerated pure water at $180^{\circ} \mathrm{C}$ (SEM observation).

Table 2 Summary of effect of surface oxidation on metal release and surface film.

\begin{tabular}{|c|c|c|c|c|c|c|c|c|c|}
\hline \multirow{3}{*}{ Treotment } & \multirow{3}{*}{\begin{tabular}{|c|}
$\begin{array}{l}\text { Relative } \\
\text { Metol Release } \\
\text { Level }\end{array}$ \\
1
\end{tabular}} & \multicolumn{8}{|c|}{ Change of Surface Film by Immersion ${ }^{* 1}$} \\
\hline & & \multicolumn{2}{|c|}{ Adhesion $^{* 2}$} & \multicolumn{2}{|c|}{ Fineness } & \multicolumn{2}{|c|}{ Thickness ( $A$ ) } & \multicolumn{2}{|c|}{ Structure } \\
\hline & & - & - & - & - & $\begin{array}{c}30 \\
1 \\
40\end{array}$ & $\begin{array}{l}600 \\
800\end{array}$ & - & \\
\hline $\begin{array}{l}\text { Air-oxidized } \\
\left(425^{\circ} \mathrm{C} \times(\mathrm{h})\right.\end{array}$ & $\approx 1 / 3$ & (2) & (2) & (O) & & 200 & $\left.-{ }^{600}\right\}$ & $\begin{array}{c}\mathrm{Fe}_{2} \mathrm{O}_{3} \\
+ \\
+ \\
\mathrm{FeCr} 2 \mathrm{O}_{4}\end{array}$ & $\begin{array}{c}\mathrm{NiFe2O4} \\
+ \\
\mathrm{Fe}_{2} \mathrm{O} 3\end{array}$ \\
\hline $\begin{array}{l}\text { Steam- oxidized } \\
\left(350^{\circ} \mathrm{C} \times(0 \mathrm{~h})\right.\end{array}$ & $\approx 1 / 20$ & (2) - & (2) & (C) & D & 600 & -600 & \begin{tabular}{|l|}
$\mathrm{Fe}_{2} \mathrm{O}_{3}$ \\
$\left(\mathrm{Fe}^{+} \mathrm{Ni}\right) \mathrm{O}$ \\
$\mathrm{Cr}_{2} \mathrm{O}_{3}$
\end{tabular} & $\begin{array}{c}+ \\
(\mathrm{Fe}, \mathrm{Ni}) \mathrm{O} \\
\mathrm{Cr}_{2} \mathrm{O}_{3}\end{array}$ \\
\hline $\begin{array}{l}\text { Woter-oxidized } \\
\left(350^{\circ} \mathrm{C} \times 24 \mathrm{~h}\right)\end{array}$ & $\simeq 1 / 1.5$ & C & 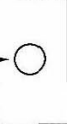 & $x$ & X & 1000 & $\begin{array}{c}600 \\
5 \\
800\end{array}$ & $\begin{array}{l}\mathrm{Fe}_{2} \mathrm{O}_{3} \\
\left(\mathrm{Fe}^{+}, \mathrm{NiO}\right. \\
\mathrm{Cr}_{2} \mathrm{O}_{3}\end{array}$ & \\
\hline
\end{tabular}

* 1: 3 monthes immersion in deaerated pure water at $180^{\circ} \mathrm{C}$

* 2: () Excellent, OGood, $x$ Poor 


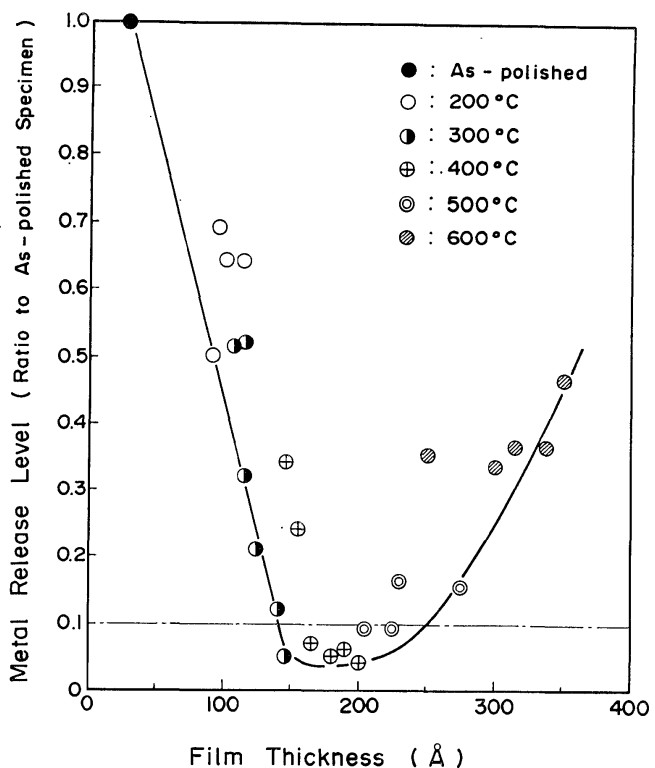

Fig. 12 Relationship between metal release level and film thickness of airoxidized specimens ( 2 weeks, immersion in deaerated pure water at $180^{\circ} \mathrm{C}$ ).

ままでも比較的大きな粒状の構造を示しているが，3 カ 月間浸漬後にはさらに粗大な粒状の表面構造に変化して いることがわかる。

\section{4. 考察}

\section{1 最適酸化処理条件}

Fig. 3 及び 4 より金属放出量を最小にする観点から， 大気中水蒸気中及び水中酸化処理のそれぞれについて最
高条件として $425^{\circ} \mathrm{C} \times 1$ 時間, $350^{\circ} \mathrm{C} \times 10$ 時間及び $350^{\circ} \mathrm{C} \times 24$ 時間を選定した。

Fig. 12 は大気中酸化処理材についてェリプソメトリ 一法により測定した酸化皮膜厚さと高温脱気純水中浸漬 後の金属放出量との関係を示すもので，皮膜厚さ約 200 $\AA$ 付近で金属放出量の最小值が存在することがわかる。 皮膜厚さ約 $200 \AA$ までは皮膜厚さの増加と共に金属放 出量が減少するのは酸化皮膜が金属及び環境側の物質移 動を律速して金属放出を抑制するためてであり，約 200 A 以上に成長するとむしろ金属放出量が増大するのは 膜厚の増大と共に皮膜の欠陥が多くなり，金属放出抑制 作用が低減するためと考えられる。

\section{2 各酸化処理間の比較}

Table 2 は非処理材も含め各酸化処理材について金属 放出量及び浸漬前後に打ける表面皮膜性状の変化をまと めたものである。なお, Table 2 中の密着性は碁番目試験 によって得られた定性的な評価, 緻密性は表面の SEM 観察によって得られた定性的な評価, 膜厚は AES の indepth プロファイル及びェリプソメトリーによる測定デ ータをもとに算出した結果である。さらに，これらの観 察結果に基ついて各酸化処理材の表面皮膜の高温純水浸 漬による変化の様子を模式的に Fig. 13 に示す。

大気酸化処理材は高温純水浸漬によって皮膜厚さは増 大するが，表面皮膜は密着性，緻密性に比較的優れて特 り，金属放出量は非処理材に比べて約 $1 / 3$ に減少した。水 蒸気酸化処理材は 3 種の酸化処理間では最も表面皮膜が 安定して和り，高温純水中 3 力月間浸漬後も実質的な変 化は認められず，金属放出量は非処理材に比べて約 $1 / 20$ に減少した。一方，水中酸化処理材は表面皮膜の緻密性

$$
\begin{aligned}
& \text { Air Oxidized } \\
& \left(425^{\circ} \mathrm{C} \times 1 \mathrm{~h}\right)
\end{aligned}
$$
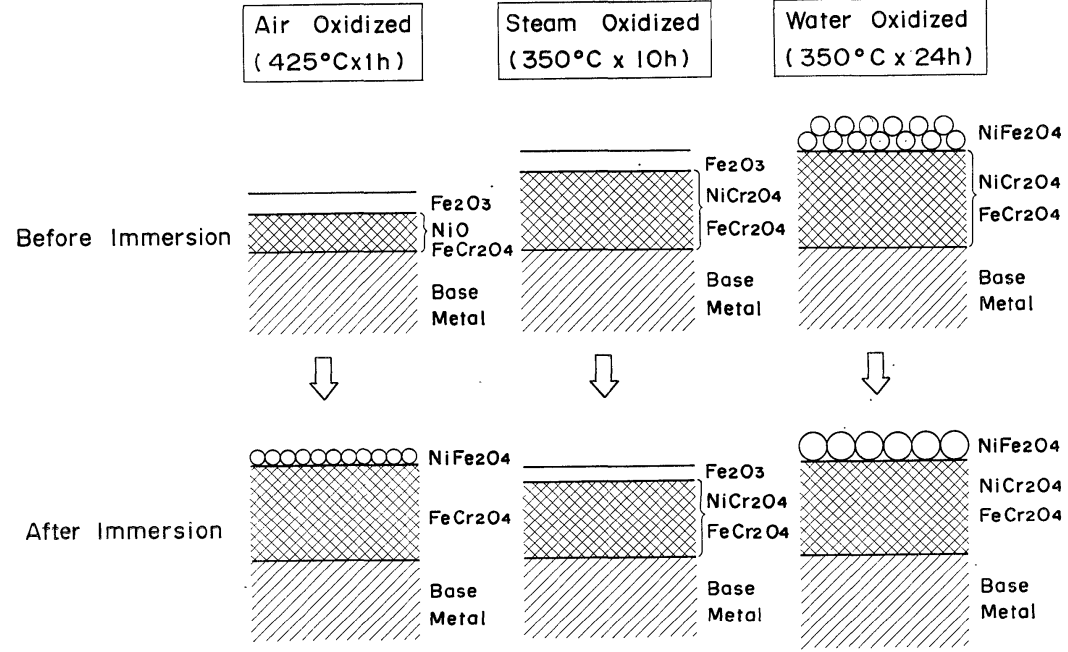

Fig. 13 Schematic illustration of surface film before and after immersion in high temperature pure water 
が良好でなく，金属放出量は非処理材に比べて約 $1 / 1.5$ 程度であった。このように, 3 種の酸化処理間では皮膜 組成上は顕著な差異は認められないが, 金属溶出抑制効 果に大きな差異が生じたのは基材との熱膨脹率の違いな ど起因する皮膜の欠陥など皮膜構造上の違いに基づくも のと考えられる。

\section{5. まとめ}

ステンレス鋼に広範囲の条件下で表面酸化処理 (大気 中, 水蒸気中, 水中) を施し, $180^{\circ} \mathrm{C}$ の高温純水中に括沙 る金属放出特性を表面皮膜性状との関連で検討した。得 られた結果をまとめると以下のよらである。

(1) 高温脱気純水中に打ける金属放出量を最小にする ための適正酸化処理条件は大気中, 水蒸気中及び水中酸 化のそれぞれそついて，425 $\mathrm{C} \times 1$ 時間及び $350^{\circ} \mathrm{C} \times 10$ 時間及び $350^{\circ} \mathrm{C} \times 24$ 時間であり, これらの処理に伴ら金 属放出抑制効果は $280^{\circ} \mathrm{C}$ の純水に各種イオンを添加し た溶液中での長時間処理材に比べて優れている。

(2) 3 種の酸化処理間での金属放出抑制効果の序列は 水蒸気酸化処理 $>$ 大気酸化処理 $>$ 水中酸化処理の順であ り, 高温純水中 3 力月間浸漬後の積算金属放出量は非処 理のそれに比して,それぞれ約 $1 / 20$, 約 $1 / 3$ 及び約 $1 / 1.5$ となった。

(3) 3 種の酸化処理皮膜はいずれも 2 層構造から成っ
ており，処理ままでは皮膜組成上顕著な差異が認められ ないが上記のごとく金属放出量抑制効果に大きな差異を 生じるのは，皮膜欠陥など皮膜の緻密性に大きな差異が あるためと考觉らる。

[謝辞〕

本論文の作製に際し琹切な御助言を賜った東京大学工 学部石榑顕吉教授並びに（財）工業開発研究所藤田矩彦 博士に対し厚く御礼申し上げます。

(Received December 2, 1986)

\section{文献}

1）石榑顕吉：防食技術, 32, 276 (1983).

2）石榑顕吉, 大沢安隆, 内田俊介：日本原子力学会 誌, 25, 337 (1983).

3）長尾博之, 逸見幸雄, 石井英臣, 佐藤康彦：日本 原子力学会誌, 23, 796 (1981).

4) T. Honda, A. Minato, M. Izumiya, K. Ohsumi, and H. Mitsubayashi: J. Nuclear Sci. \& Tech., 20, 871 (1983).

5) W. J. Marble and C. J. Wood: CORROSION/ 85, Paper No. 107.

6) W. J. Niedrach and W. H. Soddart: CORROSION/85, Paper No. 108.

7) D. L. Douglas and F. C. Zyzes: Corrosion, 13, 433t., (1957). 